Relations industrielles

Industrial Relations

\title{
Collective Bargaining and the Challenge of New Technology, Geneva, International Labour Office, 1972, 71 pp.
}

\section{Jean Sexton}

Volume 28, numéro 3, 1973

URI : https://id.erudit.org/iderudit/028431ar

DOI : https://doi.org/10.7202/028431ar

Aller au sommaire du numéro

Éditeur(s)

Département des relations industrielles de l'Université Laval

ISSN

0034-379X (imprimé)

1703-8138 (numérique)

Découvrir la revue

Citer ce compte rendu

Sexton, J. (1973). Compte rendu de [Collective Bargaining and the Challenge of New Technology, Geneva, International Labour Office, 1972, 71 pp.] Relations industrielles / Industrial Relations, 28(3), 669-670.

https://doi.org/10.7202/028431ar

Tous droits réservés @ Département des relations industrielles de l'Université Laval, 1973
Ce document est protégé par la loi sur le droit d'auteur. L’utilisation des services d'Érudit (y compris la reproduction) est assujettie à sa politique d'utilisation que vous pouvez consulter en ligne.

https://apropos.erudit.org/fr/usagers/politique-dutilisation/ 
reliés à la négociation collective mais bien davantage une sorte d'état de la situation dont l'exposé est riche de l'expérience de l'auteur dans les domaines de l'enseignement et de l'arbitrage qui fut l'occasion pour lui d'entrer en contact avec les problèmes concrets qui résultent de la négociation et de l'application des conventions collectives. Cette expérience transparait tout au long de l'ouvrage aussi bien au niveau de l'illustration des problèmes abordés que dans l'approche analytique elle-même.

Dans cette perspective, cet ouvrage peut être considéré comme un très bon livre d'introduction à la négociation collective aussi bien pour l'étudiant que pour le praticien.

\section{Jean BERNIER}

\section{Université Laval}

\section{Collective Bargaining and the Challenge} of New Technology, Geneva, International Labour Office, 1972, $71 \mathrm{pp}$.

En 1963, l'Organisation internationale du travail adoptait une recommandation (no 119) concernant la cessation de la relation de travail à l'initiative de l'employeur. Cette recommandation non modifiée depuis son adoption, s'applique tant aux licenciements individuels que collectifs. Elle accepte entre autres les principes du licenciement pour motif valable, du préavis, du droit de recours des travailleurs, de l'utilisation des services publics et de la consultation. L'OIT propose que ces principes soient mis en application par une série de moyens dont la liste n'est sûrement pas exhaustive : loi, décrets, convention collective, décision arbitrale, etc.

Par cet ouvrage l'OIT veut faire un tour d'horizon des moyens prévus par certaines conventions collectives en certains pays pour appliquer les principes énoncés dans la recommandation no 119. $\mathrm{La}$ recherche que nous complétons présentement fait pour sa part un tour d'horizon des programmes publics directs visant l'application de ces mêmes principes aux Etats-Unis, en Grande-Bretagne, en France et au Québec.

Le sujet traité dans Collective Bargaining and the Challenge of New
Technology n'est sûrement pas nouveau. Ce qui fait le mérite particulier de cette publication est son caractère international et comparatif. C'est en fait un ouvrage du type de celui de Yves Delamotte, Les partenaires sociaux face aux problèmes de productivité et d'emploi, publié à l'OCDE. Cet aspect comparatif est sûrement très instructif, même pour le lecteur averti. Comme les auteurs le mentionnent au début de leur étude,

« Clearly, the bargaining context in each country is affected by different historical, political, economic, and cultural developments : the resulting collective agreements will therefore differ accordingly and demonstrate a variety of possible responses to the challenges of technological change ».

De plus, les auteurs se concentrent exclusivement sur ces conventions collectives qui indiquent clairement une réponse à l'introduction d'un changement technologique. Une telle contrainte nous empêche de connaître dans quelle proportion les parties s'attaquent réellement au problème des changements technologiques. En plus, on n'y retrouvera généralement pas de référence à ces clauses visant d'autres changements que les changements technologiques, ni à ces clauses ne visant qu'indirectement les changements technologiques.

Cette publication de l'OIT comprend deux chapitres. Le premier s'attarde aux différentes clauses directes adoptées en différents pays pour faire face aux problèmes posés par les changements technologiques. Le chapitre II, pour sa part, présente quelques accords d'entreprises ou d'industries au Canada. en France, en Allemagne et aux Etats-Unis. Il serait trop long ici de présenter en détail ces clauses ou ces accords décrits dans cette publication.

Même si, par la nature même du sujet traité, il ne faut sûrement pas s'attendre à une étude exhaustive, l'absence d'une conclusion générale représente une faiblesse sérieuse à cette publication, le sujet s'y prêtant très bien et l'expérience des auteurs le permettant sûrement. Le lecteur intéressé pourra cependant tirer ses propres conclusions à partir de cet ouvrage bien structuré et bien présenté. 
Même si le sujet n'est pas nouveau, la solution idéale à ce problème n'a pas encore été trouvée. Il reste donc encore beaucoup de travail imaginatif à faire. Cet ouvrage est une contribution valable et constitue un document de travail nécessaire à celui qui veut continuer de travailler dans ce domaine.

\section{Jean SEXTON}

\section{Université Laval}

\section{Competition and Collective Bargaining} in the Needle Trades, 1910-1967, by Jesse Thomas Carpenter, Ithaca, The New York State School of Industrial and Labor Relations, Cornell University, 1972, $910 \mathrm{pp}$.

In this exhaustive study, Volume XVII of the Cornell Studies in Industrial and Labor Relations, Professor Carpenter details the development of the industrial relations system in the needle trades.

The labour movement has long sought to take labour out of competition. In a group of industries where, at least until very recently, the only significant potential cost differencial between firms was the cost of labour, the desire for total organization by the unions can readily be seen, as can the potential for using the collective bargaining process to regulate competition.

Professor Carpenter shows how manufacturers, through their employer's associations, and the unions in the needle trades have worked closely together over many years to advance their mutual interests. The basic goal of the relationship has been to eliminate cutthroat competition, basically by enforcing uniform labour standards. Of course, the goal has not always been easily met. The almost atomistic structure of the industry as well as the ease of entry and exit, meant that the unions were the only really stable entities involved and also that continuing relationships were difficult to maintain.

The book describes what have been continuing attempts to regulate competition through collective bargaining and the elaborate joint machinery - inspection, mediation, arbitration, and fines (as well as unilaterally imposed strikes) - used by the parties to enforce the agreements reached between employers' associations and the unions. The agreements reached concerned themselves with a far wider ranging agenda than that usually associated with collective agreements, including such items as prices and relationships between manufacturers and their suppliers and sub-contractors.

Obviously, collective bargaining arrangements such as those in the needle trades can run afoul of the antitrust laws. Professor Carpenter describes the problems the parties have faced in avoiding government prosecution, particularly since the Allen Bradley decision of 1945. One of the parties' responses to anti-trust pressure has been to make the arrangements between them much less explicit, and the richness of detail which characterizes the author's description of collective bargaining activity prior to World War II is of necessity missing in the later chapters.

Canadian readers seeking information on the operation of the same unions in collective relationships in Canada will find no material in this book on the subject. It is exclusively devoted to U.S. experience.

Nevertheless, the story of collective bargaining in the needle trades is a fascinating one, and anyone interested in understanding how involved collective bargaining can be and how large an agenda is can involve itself with would be advised to examine this book. Certainly, anyone interested in understanding collective bargaining in the needle trades would find it indispensable.

One very minor criticism is that the book fails to be a really complete record of the development of collective bargaining practices in the needle trades. It would not have taken much more time or space to briefly trace the development of some of the unions and some of the industries prior to the Brandeis Conferences of 1910 which marked the beginning of the intermingling of trade relations and industrial relations in the garment industries.

\section{David A. Peach}

\section{The University of Western Ontario}

